\title{
Dutch House Martins Delichon urbicum gain blood parasite infections over their lifetime, but do not seem to suffer
}

\author{
Theunis Piersma • Marco van der Velde
}

Received: 28 July 2011/Revised: 10 January 2012/ Accepted: 30 January 2012/Published online: 21 February 2012

(C) The Author(s) 2012. This article is published with open access at Springerlink.com

\begin{abstract}
In a southern Spanish population of the colonial-breeding Afrotropical migrant House Martins Delichon urbicum, a high overall prevalence of (molecularly assayed) haemosporidian infections (in the non-parasitological literature usually denoted with the inclusive term 'malaria') was associated with negative fitness consequences for individuals carrying single or double infections. To verify this in a northern population, we here report on the occurrence of malaria in 112 fledgling and 358 adult House Martins from The Netherlands. Repeatability of molecular essays was $94.4 \%(n=125)$. Malaria was not found in any of the fledglings, but $77 \%$ of the adults carried single or double infections of two Haemoproteus haplotypes (Delurb1, Delurb2) and five Plasmodium haplotypes (GRW2, GRW9, GRW11, COLL6 and Turdus1). The two Haemoproteus and two of the Plasmodium haplotypes overlapped with nine haplotypes observed in Spain, with Dutch birds showing another four. Haemoproteus infections were common (occurring in $70 \%$ of adult samples) and Plasmodium was rare (9\%). Molecularly sexed females with blood parasite infections tended towards a higher chance of double infection (33\%) than males $(23 \%)$. Of 64 cases of birds captured in successive
\end{abstract}

Communicated by F. Bairlein.

T. Piersma $(\square) \cdot$ M. van der Velde

Animal Ecology Group, Centre for Ecological and Evolutionary

Studies, University of Groningen, P.O. Box 11103,

9700 CC Groningen, The Netherlands

e-mail: theunis.piersma@nioz.nl

T. Piersma

Department of Marine Ecology, Royal Netherlands Institute for

Sea Research (NIOZ), P.O. Box 59, 1790 AB Den Burg,

Texel, The Netherlands years, $23 \%$ showed no change in infection status, $5 \%$ lost infection, and there was an $85 \%$ chance for adults to gain a 'malaria' type. Within a single breeding season, infection status did not change in 6 of 13 cases (46\%). However, in 6 of the 7 cases of change $(86 \%)$, there was loss of a Haemoproteus infection. Infection status did not correlate with body mass or body size, tail asymmetry, occurrence of louse flies, nor with the likelihood of recapture in the subsequent year. The limited evidence so far suggests that House Martins get infected away from the European breeding grounds.

Keywords Avian malaria $\cdot$ Haemosporidians . Plasmodium - Haemoproteus . Sex differences . Geographic differences

\section{Zusammenfassung}

Holländische Mehlschwalben Delichon urbicum werden im Laufe ihres Lebens von Blutparasiten befallen, leiden jedoch anscheinend nicht darunter

In einer südspanischen Population der Mehlschwalbe Delichon urbicum, einem koloniebrütenden afrotropischen Zugvogel, war eine hohe Gesamtprävalenz von (molekular geprüften) Hämosporidieninfektionen (in der nicht-parasitologischen Literatur gewöhnlich mit dem Pauschalbegriff "Malariabezeichnet") mit negativen Fitnesskonsequenzen für Individuen, die Einfach- oder Doppelinfektionen trugen, verbunden. Um dies in einer nördlichen Population zu überprüfen, berichten wir hier über das Auftreten von Malaria bei 112 flüggen und 358 adulten Mehlschwalben aus den Niederlanden. Die Wiederholbarkeit der molekularen Tests betrug 94.4\% $(n=125)$. Bei keinem der Flügglinge wurde Malaria festgestellt, jedoch trugen $77 \%$ 
der Altvögel Einfach- oder Doppelinfektionen mit zwei Haemoproteus-Haplotypen (Delurb1, Delurb2) und fünf Plasmodium-Haplotypen (GRW2, GRW9, GRW11, COLL6 and Turdus1). Die beiden Haemoproteus- und zwei der Plasmodium-Haplotypen deckten sich teilweise mit neun in Spanien festgestellten Haplotypen, während bei niederländischen Vögeln vier weitere Haplotypen vorkamen. Haemoproteus-Infektionen waren häufig (sie wurden in $70 \%$ der Altvogel-Proben nachgewiesen) und Plasmodium selten (9\%). Das Risiko einer Doppelinfektion war für molekular geschlechtsbestimmte Weibchen mit Blutparasiten tendenziell höher (33\%) als für Männchen (23\%). Von 64 in aufeinanderfolgenden Jahren gefangenen Vögeln zeigten 23\% keine Änderung ihres Infektionsstatus, 5\% verloren ihre Infektion, und für Altvögel bestand eine 85\%iges Risiko, Malaria zu bekommen. Innerhalb einer einzigen Brutsaison änderte sich der Infektionsstatus in 6 von 13 Fällen (46\%) nicht. In 6 der 7 Fälle (86\%), in denen sich der Infektionsstatus änderte, wurde eine HaemoproteusInfektion verloren. Der Infektionsstatus korrelierte weder mit der Körpermasse oder -größe, der Asymmetrie der Schwanzfedern oder dem Auftreten von Lausfliegen noch mit der Wahrscheinlichkeit des Wiederfangs im folgenden Jahr. Die limitierten Befunde deuten bislang darauf hin, dass Mehlschwalben außerhalb ihrer europäischen Brutgebiete infiziert werden.

\section{Introduction}

It is now clear that any effects of parasitic infectionsincluding blood parasites popularly known as avian malaria in the non-parasitological literature-on their hosts are highly dependent on the precise host-parasite association and the ecological context in which the host-parasite interactions are played out (e.g. Bensch et al. 2007; Zehtindjiev et al. 2008; Hellgren et al. 2009; Palinauskas et al. 2011). Even though general associations between avian malaria diversity and host life-history characteristics at the species level have been published (Arriero and Møller 2008), the degree to which particular fitness effects can be assumed to exist beyond a locally studied hostparasite system could do with more investigation.

House Martins Delichon urbicum breed in colonies and migrate long distances to moult and winter in areas somewhere south of the Sahara (Wernham et al. 2002; Turner 2004; Ambrosini et al. 2011; K.A. Hobson, S. Van Wilgenburg, L.I. Wassenaar, T. Piersma, unpublished data). For birds breeding in Badajoz, southern Spain, Marzal et al. (2008) showed strong effects of malarial infection on survival, body mass and ectoparasite abundance, with individuals molecularly shown to carry double infections (i.e. harbouring two malaria haplotypes) doing worst. During an experimental study at the same colony, prelaying House Martins were either or not treated with an antimalarial drug (Marzal et al. 2005). This reduced the prevalence of malaria and increased reproductive success. Interestingly, again in this colony, experimentally altered infestation levels of an ectoparasite did not affect the presence or absence of malaria assayed from blood smears (Christe et al. 2002).

To see whether such negative effects occur widely in this common and widespread Eurasian songbird species, we here provide a comparison, employing the same set of general and molecular techniques, between the House Martins from southern Spain and ones breeding almost $2,000 \mathrm{~km}$, and 14 geographical degrees, further north in a village in the northern Netherlands. As we shall see, although the molecularly measured prevalences of single and double infection are quite similar to those in Spain, the Dutch birds show little sign of suffering any effects on mass, ectoparasite burden or survival, at least during the study period 2005-2011. Differences between young and old birds, and between adult birds captured in different years, enabled us to additionally discuss whether the haemosporidian strains found in Dutch breeding birds would be transmitted during the breeding season or elsewhere during the annual cycle.

\section{Materials and methods}

Study site and field methods

This study was carried out in the small village of Gaast $\left(53^{\circ} 01^{\prime} \mathrm{N}, 05^{\circ} 24^{\prime} \mathrm{E}\right)$, in the province of Friesland, The Netherlands, in June-August 2005-2011 (Piersma 2008; Piersma and van der Velde 2009). We used a variety of catching methods. We mostly mist-netted in late afternoons and early evenings, but also used small butterfly nets held at the entrance of individual nests during daytime, and in a few cases, captured birds upon their emergence from the nest at dawn with a variety of nets. Both adults and recently fledged House Martins were captured, with catching mostly taking place as the breeding seasons were well underway (earliest date was 11 June and the latest 26 August). Young birds which fledged recently were identified on the basis of the white trailing edges of their tertials (Cramp 1988).

As soon as possible, but always within $1.5 \mathrm{~h}$ after capture, the birds were processed and released. The birds were ringed with an aluminium ring and weighed to the nearest $0.1 \mathrm{~g}$ on an electronic balance. We measured the length of the wing (maximum chord of folded wing, to the nearest $\mathrm{mm}$ ), the length of the keel (to the nearest $0.1 \mathrm{~mm}$, with an easily sliding calliper; see Bryant and Westerterp 1980), and the length of the two outermost and the two innermost 
tail feathers (enabling the calculation of tail asymmetry; see Møller 1990). If present, numbers of louse flies (Crataerina hirundinis, Diptera: Hippoboscidae; see Summers 1975) were noted. All measurements were done by a single observer (T.P.). A droplet of blood was collected from the brachial vein after a small puncture with a sterilised needle. The blood was drawn into a heparinized microcapillary tube, the puncture closed with a piece of cotton wool, and the blood stored in $96 \%$ alcohol at $-20^{\circ} \mathrm{C}$ before DNA extraction.

Molecular essays

Birds were sexed following Griffiths et al. (1998): PCR amplification of a part of the CHD gene that is located on the sex chromosomes. PCR products were separated on 3\% agarose gels with males showing one band and females two bands. The method was also verified using other molecular assays (Piersma and van der Velde 2009).

Haemosporidian infections were detected from blood samples using the molecular methods described in Hellgren et al. (2004) and Waldenström et al. (2004). DNA was extracted from blood using a chelex extraction method (Walsh et al. 1991). This DNA was then used in a nested-PCR assay of Hellgren et al. (2004) to amplify the cytochrome $b$ gene of the parasites Plasmodium and Haemoproteus (primers HaemNFI, HaemNR3 and HaemF, HaemR2). To evaluate the PCR-amplification, $5 \mu$ of the final PCR of each sample was run on a $2 \%$ agarose gel together with 1 negative control for (on average) every 8 samples. Birds were scored as being infected if a \pm 530 -bp band was visible on the gel, or scored as uninfected when such a band was absent. Samples that showed positive amplification were sequenced with primer HaemF on an AB3730 DNA analyser using Big Dye Terminator v. 3.1 Cycle Sequencing Kit (Applera, The Netherlands). Sequences were edited manually and aligned using BIOEDIT version 7.0.5.3 (Hall 1999). Mixed infections were identified as 'double base calling' in the electropherogram. Finally, using the search function of GenBank (http:// www.ncbi.nlm.nih.gov), we assigned our sequences to known malaria cytochrome $b$ gene lineages if there was a $100 \%$ match between one of our sequences and a published sequence in GenBank. In addition, we consulted the MalAvi database compiled by S. Bensch (Bensch et al. 2009; http://mbioserv4.mbioekol.lu.se/avianmalaria/index.html) to gain insight into the geographic distribution of the observed malaria lineages.

\section{Repeatability}

The repeatability of the method was estimated by running 125 House Martin DNA samples twice (from years 2005 to
2008). Of these 125 samples, 118 showed the same result, absence or presence of haemosporidians in both runs (repeatability $=94.4 \%$ ). The repeatability between different DNA extractions from the same blood sample was $88.5 \%$ ( $n=26$ blood samples from year 2009).

\section{Statistics}

The comparison of frequencies was performed with simple and robust $\chi^{2}$ tests. All statistics were carried out in SYSTAT 13.

\section{Results}

In none of the 112 blood samples of young House Martins from the weeks after fledging an infection with blood parasites was found (Table 1). This contrasts with a prevalence of $77 \%$ in 358 samples from adult birds. In 77 out of the 276 positive cases (28\%), the blood samples showed two haplotypes, i.e. these birds carried double infections (Table 1). Prevalence of infections were lower in the breeding seasons of $2005(76 \%)$ and 2008 (63\%) compared with the remaining years (ca. 83\%), the variation between years being significant $\left(\chi^{2}=14.2, d f=5, P=0.014\right)$, but not controlled for in the subsequent analyses because of limited sample sizes.

Seven different haplotypes were identified (Table 2), two belonging to the Haemoproteus group (Delurb1, Delurb2) and five to the Plasmodium group (GRW2, GRW9, GRW11, COLL6 and Turdus1). Only two of these seven lineages have been identified to (morpho-)species. GRW2 was identified as Plasmodium ashfordi (Valkiūnas et al. 2007) and Turdus1 as Plasmodium circumflexum (Palinauskas et al. 2007). Haemoproteus infections were most

Table 1 Breakdown of sample sizes per year of fledgling and adult House Martins assayed for blood parasites

\begin{tabular}{|c|c|c|c|c|c|}
\hline \multirow[t]{2}{*}{ Year } & \multirow{2}{*}{$\begin{array}{l}n_{\text {fledlings }} \\
\text { not } \\
\text { infected }\end{array}$} & \multicolumn{3}{|l|}{$n_{\text {adults }}$} & \multirow{2}{*}{$\begin{array}{l}\% \text { Adults } \\
\text { infected }\end{array}$} \\
\hline & & $\begin{array}{l}\text { Not } \\
\text { infected }\end{array}$ & $\begin{array}{l}\text { With } 1 \\
\text { haplotype }\end{array}$ & $\begin{array}{l}\text { With } 2 \\
\text { haplotypes }\end{array}$ & \\
\hline 2005 & 1 & 5 & 12 & 4 & 76 \\
\hline 2006 & 21 & 5 & 20 & 5 & 83 \\
\hline 2007 & 24 & 13 & 51 & 12 & 83 \\
\hline 2008 & 24 & 33 & 39 & 17 & 63 \\
\hline 2009 & 30 & 17 & 47 & 26 & 81 \\
\hline 2010 & 12 & 9 & 30 & 13 & 83 \\
\hline Totals & 112 & 82 & 199 & 77 & $n_{\text {total }}=358$ \\
\hline
\end{tabular}

This includes 65 birds recaptured $2-3$ times as adults in different years 
Table 2 Occurrence of different haplotypes of Haemoproteus and Plasmodium in adult House Martins in The Netherlands during the breeding seasons 2005-2010

\begin{tabular}{|c|c|c|c|c|c|c|c|c|}
\hline \multirow[t]{2}{*}{ Genus } & \multirow[t]{2}{*}{ Haplotype } & \multirow{2}{*}{$\begin{array}{l}\text { GenBank } \\
\text { accession no. }\end{array}$} & \multirow{2}{*}{$\begin{array}{l}n \text { occurring } \\
\text { alone }\end{array}$} & \multicolumn{4}{|c|}{$n$ occurring together with } & \multirow{2}{*}{$\begin{array}{l}n \text { occurring } \\
\text { in combo }\end{array}$} \\
\hline & & & & Delurb2 & GRW9 & GRW2 & COLL6 & \\
\hline Haemoproteus & Delurb $1^{\mathrm{a}}$ & EU154343 & 131 & 66 & 2 & 3 & 1 & 72 \\
\hline Haemoproteus & Delurb2 $^{\mathrm{a}}$ & EU154344 & 43 & - & 1 & 0 & 0 & 67 \\
\hline Plasmodium & GRW9 & DQ060773 & 10 & $\mathrm{X}^{\mathrm{b}}$ & - & 0 & 1 & 4 \\
\hline Plasmodium & GRW2 & AF254962 & 8 & 2 & $\mathrm{X}$ & - & 0 & 5 \\
\hline Plasmodium & GRW11 & AY831748 & 1 & 1 & 0 & 0 & 0 & 1 \\
\hline Plasmodium & COLL6 & DQ368375 & 2 & $X$ & $X$ & $X$ & - & 2 \\
\hline Plasmodium & Turdus1 & AF495576 & 1 & 0 & 0 & 0 & 0 & 0 \\
\hline
\end{tabular}

The $n$ value refers to the occurrences of a parasite, not to numbers of sampled birds

${ }^{a}$ Marzal et al. (2008) use the names Durb1 and Durb2, but the names in GenBank and MalAvi are Delurb1 and Delurb2

${ }^{\mathrm{b}} \mathrm{X}$ indicates if the particular combination is already listed in a row above

common (occurring in 251 or $70 \%$ of adult samples), and Plasmodium was quite rare $(9 \%)$.

The incidence of blood parasites in molecularly sexed males and females did not differ much $(75 \%$ in 177 males and $79 \%$ in 170 females; $\chi^{2}=0.7, d f=1, P=0.416$ ), but positive females tended towards a higher chance of double infection (33\%, $n=134)$ than males $(23 \%, n=133)$ $\left(\chi^{2}=3.0, d f=1, P=0.083\right)$. There was strong coinfection of the two common Haemoproteus lineages, Delurb1 and Delurb2, and both of these occasionally occurred together with one of the Plasmodium lineages (Table 2). There was only a single occasion of a double infection with two Plasmodium lineages, in a bird that combined GRW9 and COLL6.

For birds resampled within a single breeding season (2009) at intervals of 3-23 days (average of 17 days), in 6 of 13 cases (46\%), infection status remained identical, and in 6 of the 7 cases of change (86\%), there was loss of a Haemoproteus infection. However, the odds of becoming (re-)infected with blood parasites between successive breeding seasons were higher than the odds of losing an infection (Table 3). If clean as an adult, there was an $85 \%$ chance (17/20) of returning with an infection in a later

Table 3 Repeatability of malaria infection status in adult House Martins captured in multiple (usually successive) breeding seasons (2005-2010)

\begin{tabular}{lcc}
\hline Later year & \multicolumn{2}{l}{ First year } \\
\cline { 2 - 3 } & Not infected & Infected \\
\hline Not infected & 3 & 10 \\
Infected & 17 & - \\
Infected by same type(s) & - & 12 \\
Infected by different type(s) & - & 22 \\
\hline
\end{tabular}

Values refer to the number of occasions year. When already infected, there was a $23 \%$ chance (10/ 44) of returning clean. Also, for those birds that remained infected between years, the chances of returning with the same haplotype(s) $(35 \%, 12 / 34)$ was smaller than the chance of returning with a different one or a different combination $(65 \%, 22 / 34)$. In these cases of change, in 4 cases there was a loss of a lineage $(18 \%, 4 / 22)$, in 11 cases $(50 \%)$ there was a gain, and in 7 cases $(32 \%)$ there was a complete change in the malarial haplotypes found. In 6 of 18 cases $(33 \%)$ of a change or a gain, a Plasmodium rather than a Haemoproteus was involved, and thus the odds of gaining a Plasmodium infection was rather higher than their overall relative occurrence in the population (34/ $313=11 \%$, Table 2).

We tried hard to find associations between infection status and body mass, wing and keel length, and various measures of outer and inner tail feather asymmetry of the adult House Martins, but were unable to find any such relationships. The slight tendency of birds carrying louse flies Crataerina hirundinis to show a greater rate of double infections (20\%, $n=262)$ than birds without $(26 \%$, $n=96)$ was certainly not statistically significant $\left(\chi^{2}=1.6\right.$, $d f=2, P=0.448$ ). Of the birds without a haemosporidian infection in the first year of capture, $13(18.6 \%)$ were recaptured in the subsequent year (including data from July 2011). Of the 232 birds that carried haemosporidians in the first year of capture, 48 (20.7\%) were recaptured a year later, making it unlikely that infection status affected local survival $\left(\chi^{2}=0.2, d f=1, P=0.699\right)$.

\section{Discussion}

The two Haemoproteus and two of the Plasmodium haplotypes overlapped with the nine haplotypes observed in Spain (Marzal et al. 2008), with the Spanish populations 
showing another four haplotypes (one Haemoproteus and three Plasmodium) and the Dutch population yet another four (all Plasmodium). Although the most common malaria lineages (Delurb1 and Delurb2) are shared between the Spanish and the Dutch populations, the occurrence of unique Plasmodium lineages including those from Great Reed Warblers Acrocephalus arundinaceus (GRW2 and GRW11 in both Spanish and Dutch breeding birds, GRW9 only in Dutch birds and GRW4 only in Spanish birds) of which transmission has been suggested to take place in Africa (Bensch et al. 2007), suggest that Spanish and Dutch breeding birds may show differences in the areas of occurrence outside the breeding season.

Rates of infection (71\% in 112 Spanish cases and 77\% in 358 Dutch cases) were perhaps somewhat higher in the Dutch birds, which comes as a surprise as another north European breeding population in Denmark has been stated to be free of Haemoproteus ( $n=55$ birds; A.P. Møller in Marzal et al. 2005). The relative occurrence of double infections (16\% in Spanish and 28\% in Dutch birds showing malaria) is again somewhat higher in the Dutch population. As the molecular detection of malaria infections has its limitations (Palinauskas et al. 2006), and as especially the prevalence double infections may be underestimated (Martínez et al. 2009), these percentages may underestimate the true double infection rates. The negative associations between being infected by 'malaria' and body mass, ectoparasite abundance and local survival for the birds in southern Spain (Marzal et al. 2008) appear absent in the Dutch population (note that in Spain, chewing lice were examined rather than the louse flies in The Netherlands). Perhaps astoundingly, clear cut patterns such as the associations reported for House Martins in Spain can thus not be extrapolated even within a single species. The immense challenge will be to come to grips with the ecological and organismal modifying factors moulding the effects of such endoparasitic parasites on organismal performance.

That the 'methodological' repeatability (89-94\%) is so much higher than the repeatability $(46 \%)$ between different blood samples from the same bird in the same year, gives us confidence that the differences in blood parasite infections from week to week and from year to year are not indicative of a faulty method. This means that the absence of haemosporidians in the young birds that have not yet been to Africa (similar to what has been described for Great Reed Warblers by Bensch et al. 2007), and the gains (rather than the losses) of infections (especially Plasmodium) in returning adults, would suggest that the blood parasites carried by House Martins are transmitted on the as yet unknown African wintering grounds or during migration. In fact, for the most prevalent parasite lineages Delurb1, Delurb2, GRW2 and GRW9, there is no evidence for transmission in Europe, as these lineages are not reported for European resident birds (AviMal database; Waldenström et al. 2002; Bensch et al. 2007). For GRW2 and GRW9, there appears to be active transmission in Africa, but for Delurb1 and Delurb2, there is no such evidence, as they have only been found in adult House Martins caught in Spain, Hungary and The Netherlands. Transmission away from the breeding grounds is puzzling, as House Martins are rarely reported to touch ground and may be in flight all the time away from the breeding grounds (and thus difficult to access by vectors), but it would explain why Christe et al. (2002) found no effect of manipulated ectoparasite levels in the nest on the incidence of haemosporidian infections. Rather tantalizingly, the fact that in 6 of the 7 cases of change (86\%) within a season there was loss of a Haemoproteus infection, hints at some House Martins under some conditions being able to shed malaria infections from the blood stream during breeding, but quite clearly this suggestion needs following up.

Acknowledgments We thank the people of Gaast for their hospitality towards House Martins and their catchers, and especially Jan van Dijk and Petra de Goeij for so much help during catching, banding and bleeding sessions. Staffan Bensch helped us accessing MalAvi and Christiaan Both who made us wonder how flying House Martins could get infected. Robert E. Ricklefs and Jordi Figuerola helped with the manuscript, as did two anonymous reviewers.

Open Access This article is distributed under the terms of the Creative Commons Attribution License which permits any use, distribution, and reproduction in any medium, provided the original author(s) and the source are credited.

\section{References}

Ambrosini R, Orioli V, Massimino D, Bani L (2011) Identification of putative wintering areas and ecological determinants of common house martin (Delichon urbicum) and common swift (Apus apus) breeding in northern Italy. Avian Cons Ecol 6(1):3 http://dx.doi. org/10.5751/ACE-00439-060103

Arriero E, Møller AP (2008) Host ecology and life-history traits associated with blood parasite species richness in birds. J Evol Biol 21:1504-1513

Bensch S, Hellgren O, Pérez-Tris J (2009) MalAvi: a public database of malaria parasites and related haemosporidians in avian hosts based on mitochondrial cytochrome b lineages. Mol Ecol Res 9:1353-1358

Bensch S, Waldenström J, Jonzén N, Westerdahl H, Hansson B, Sejberg D, Hasselquist D (2007) Temporal dynamics and diversity of avian malaria parasites in a single host species. J Anim Ecol 76:112-122

Bryant DM, Westerterp KR (1980) The energy budget of the house martin (Delichon urbica). Ardea 68:91-102

Christe P, Møller AP, González G, de Lope F (2002) Intraseasonal variation in immune defence, body mass and hematocrit in adult house martins Delichon urbica. J Avian Biol 33:321-325

Cramp S (ed) (1988) The birds of the western Palearctic, vol 5. Oxford University Press, Oxford 
Griffiths R, Double MC, Orr K, Dawson RJG (1998) A DNA test to sex most birds. Mol Ecol 7:1071-1075

Hall TA (1999) BioEdit: a user-friendly biological sequence alignment editor and analysis program for Windows 95/98/NT. Nucleic Acid Symp Ser 41:95-98

Hellgren O, Pérez-Tris J, Bensch S (2009) A jack-of-all-trades and still a master of some: prevalence and host range in avian malaria and related blood parasites. Ecology 90:2840-2849

Hellgren O, Waldenström J, Bensch S (2004) A new PCR assay for simultaneous studies of Leucocytozoon, Plasmodium and Haemoproteus from avian blood. J Parasitol 90:797-802

Martínez J, Martínez-de la Puente J, Herrero J, Del Cerro S, Lobato E, Rivero-de Aguilar J, Vásquez RA, Merino S (2009) A restriction site to differentiate Plasmodium and Haemoproteus infections in birds: on the inefficiency of general primers for detection of mixed infections. Parasitology 136:713-722

Marzal A, Bensch S, Reviriego M, Balbontin J, de Lope F (2008) Effects of malaria double infection in birds: one plus one is not two. J Evol Biol 21:979-987

Marzal A, de Lope F, Navarro C, Møller AP (2005) Malarial parasites decrease reproductive success: an experimental study in a passerine bird. Oecologia 142:541-545

Møller AP (1990) Fluctuating asymmetry in male sexual ornaments may reliably reveal male quality. Anim Behav 40:1185-1187

Palinauskas V, Dolnik OV, Valkiūnas G, Bensch S (2006) Laser microdissection microscopy and single cell PCR of avian hemosporidians. J Parasitol 96:420-424

Palinauskas V, Kosarev V, Shapoval A, Bensch S, Valkiūnas G (2007) Comparison of mitochondrial cytochrome b lineages and morphospecies of two avian malaria parasites of the subgenera Haemamoeba and Giovannolaia (Haemasporida: Plasmodiidae). Zootaxa 1626:39-50

Palinauskas V, Valkiūnas G, Bolshakov CV, Bensch S (2011) Plasmodium relictum (lineage SGS1) and Plasmodium ashfordi (lineage GRW2): the effects of co-infection on experimentally infected passerine birds. Exp Parasitol 127:527-533
Piersma T (2008) Female house martin Delichon urbica provisions chicks at nests in two separate subcolonies. Ardea 96:140-144

Piersma T, van der Velde M (2009) Breeding season-specific sex diagnostics in the monomorphic house martin Delichon urbicum. Bird Study 56:127-131

Summers RW (1975) On the ecology of Crataerina hirundinis (Diptera: Hyppoboscidae) in Scotland. J Zool Lond 175:557-570

Turner AK (2004) Family Hirundinidae (swallows and martins). In: del Hoyo J, Elliott A, Christie DA (eds) Handbook of the birds of the world, vol 9. Cotingas to pipits and wagtails. Lynx, Barcelona, pp 602-685

Valkiūnas G, Zehtindjiev P, Hellgren O, Ilieva TA, Bensch S (2007) Linkage between mitochondrial cytochrome $\mathrm{b}$ lineages and morphospecies of two avian malaria parasites, with a description of Plasmodium (Novyella) ashfordi sp. nov. Parasitol Res 100:1311-1322

Waldenström J, Bensch S, Hasselquist D, Östman Ö (2004) A new nested polymerase chain reaction method very efficient in detecting Plasmodium and Haemoproteus infections from avian blood. J Parasitol 90:191-194

Waldenström J, Bensch S, Kiboi S, Hasselquist D, Ottosson U (2002) Cross-species infection of blood parasites between resident and migratory songbirds in Africa. Mol Ecol 11:1545-1554

Walsh PS, Metzger DA, Higuchi R (1991) Chelex-100 as a medium for simple extraction of DNA for PCR-based typing from forensic material. Biotechniques 10:506-513

Wernham CV, Toms MP, Marchant JH, Clark JA, Siriwardena GM, Baillie SR (eds) (2002) The migration atlas: movements of the birds of Britain and Ireland. Poyser, London

Zehtindjiev P, Ilieva M, Westerdahl H, Hansson B, Valkiūnas G, Bensch S (2008) Dynamics of parasitemia of malaria parasites in a naturally and experimentally infected migratory songbird, the great reed warbler Acrocephalus arundinaceus. Exp Parasitol 119:99-110 